\title{
EVALUATION OF HEART FAILURE WITH PRESERVED EJECTION FRACTION IN PATIENTS WITH CORONARY HEART DISEASE AND TYPE 2 DIABETES MELLITUS*
}

\author{
O. V. Bilchenko ${ }^{1}$, K. Y. Lipakova ${ }^{1}$, T. A. Rudenko', \\ O. V. Vysotska ${ }^{2}$, A. P. Porvan ${ }^{2}$, D. Y. Karami Saliba ${ }^{1}$ \\ ${ }^{1}$ Kharkiv Medical Academy of Postgraduate Education, Kharkiv, Ukraine; \\ ${ }^{2}$ National Aerospace University — "Kharkiv Aviation Institute»; Kharkiv, Ukraine \\ ekaterinalipakova@gmail.com
}

The risk of cardiovascular complications in patients with type 2 diabetes mellitus (DM) is $2-3$ times higher than the average in the population, and the long-term prognosis is worse in patients with coronary heart disease (CHD).

Numerous studies have confirmed the relation between the diastolic dysfunction and the duration of DM: in patients with diabetes duration less than 5 years, this indicator is $37 \%$, while for patients with diabetes duration more than 5 years it increases to $50 \%[1,2]$. According to M. R. MacDonald et al. [3], where mortality was analyzed in patients with diabetes and without diabetes, depending on the ejection fraction (EF) of the left ventricle $(\mathrm{LV})$, it was noted that the highest mortality was observed in patients with diabetes and heart failure (HF) with reduced LV EF, less in patients with diabetes and $\mathrm{HF}$ with preserved LV EF. However, another study showed that the presence of type $2 \mathrm{DM}$ in patients with heart failure with preserved LV EF increases the risk of cardiovascular death or hospitalization for chronic heart failure (CHF) compared with patients with heart failure with reduced LV EF without DM [4]. Such results are due to the lack of effective therapy for this group of patients, when management strategy provides only the treatment of the underlying disease.

Studying the mechanisms of action of adverse effects of $\mathrm{DM}$ on the course of $\mathrm{CHF}$ is particularly relevant in view of the search for new treatments. Given the data, the ability

* The work was carried out in accordance with the scientific theme of the department of Internal Medicine, Nephrology and General Practice-Family Medicine of Kharkiv Medical Academy of Postgraduate Education «Cardiac and neurohumoral mechanisms of the development of chronic heart failure in patients with concomitant pathology" (State registration number: 0111U003579) and «Optimization of treatment of chronic heart failure by studying the mechanisms of development and correction myocardial dysynchrony» (State registration number: 0117U000585).

Institution, which financed the research: Ministry of Health of Ukraine.

The authors assume responsibility for the published work.

The authors guarantee absence of competing interests and their own financial interest when carrying out the research and writing the article.

The manuscript was received by the editorial staff 4.12.2019. 
to predict the course of $\mathrm{CHF}$ in patients with CHD and DM is very important.

Today, the analysis of a large amount of information requires the use of mathematical models and methods to solve complex diagnostic problems. The use of mathematical models for the diagnosis of various conditions of biological subject is presented in a number of works [5-7].

The aim of the work is to determine the course of $\mathrm{HF}$ in patients with CHD and type 2 DM, using mathematical modeling.

\section{MATERIALS AND METHODS}

An examination of 100 male patients with CHF of ischemic genesis and CHD in combination with type $2 \mathrm{DM}$ was performed. All patients were examined on the basis of the internal medicine department of the municipal non-profit enterprise City Clinical Emergency Hospital named after Prof. A. I. Meshchaninov of the Kharkiv City Council, after a course of treatment in a hospital. Inclusion criteria: age from 50 to 70 years old, CHF class I-II according to NYHA classification (New York Heart Association), LV EF $\geq 50 \%$ (according to the criteria of the European Society of Cardiology, 2016) [8], type 2 DM (according to the criteria of the American Diabetes Association (ADA) of the American Diabetes Association Diabetes Care, 2017), with a glomerular filtration rate $\geq$ $60 \mathrm{ml} / \mathrm{min} / 1.73 \mathrm{~m}^{2}$.

All examined patients were divided into two groups depending on the clinical course of HF: I ( $=66)$ - patients with a favorable course of HF (mean age - 60.0 [55.8; 63.3] years), II $(\mathrm{n}=34)$ - patients with an unfavorable course of HF (mean age 58.0 [55.0; 60.3] years) (patients with a decrease in LV EF, patients with impaired diastolic heart function, and those patients who died at the end of the observation period).

An analysis of the anamnesis, cardiovascular risk factors, objective research data, clinical, laboratory and instrumental methods of research was performed. Glycosylated hemoglobin (HbA1c) was determined in blood serum by Turbidimetric method using the Liquidirect kit (Human GmbH, Germany). Serum glucose levels were tested on a Flexor E biochemical analyzer (Vital Scientific N.V., Netherlands) using the Glucose CPL kit by the GOD-POD colorimetric method. Insulin levels were determined using the Insulin Rapid AccuBind ELISA Kits (Monobind Insulin, USA) by enzyme-linked immunosorbent assay. The insulin resistance index (HOMA) was calculated by the formula:
HOMA =

$=$ serum insulin level $\times$ glucose level $/ 22.5$.

An index value of more than 2.5 was determined as insulin resistance.

Levels of total cholesterol (TC), high density lipoprotein (HDL), low density lipoprotein (LDL) and triglyceride (TG) were determined in all patients. The atherogenic index (AI) was calculated by the formula:

$$
\mathrm{AI}=(\mathrm{TC}-\mathrm{HDL}) / \mathrm{HDL} \text {. }
$$

Transthoracic echocardiography was performed on a SiemensAcUSONSC2000 ultrasound apparatus (Siemens MedicalSolution, MountainView, USA) with a sensor from 3.5 to $7 \mathrm{MHz}$ according to the generally accepted method. The most informative indicators were evaluated: left ventricle end-diastolic volume (LVEDV), left ventricle end-systolic volume (LVESV), left atrium linear dimension (LALD), left ventricle ejection fraction (LV EF), transmitral deceleration time (Dt), left ventricle isovolumic relaxation time (IVRT), the ratio of peak velocity blood flow in early diastole to peak velocity flow in late diastole (E/A), the ratio of transmitral early filling velocity to early diastolic mitral annular velocity (E/e'), mean pulmonary artery pressure (mPAP).

Endothelium dependent dilation (EDD) of the brachial artery was evaluated by measuring reactive hyperemic response on a color flow Doppler of 5-12 $\mathrm{MHz}$ with three times measurements on the left and right brachial arteries at a 15 minute interval using the Celermajer DS method. [9] in the modification of Ivanova AV.

The follow-up interval was 12 months. All patients received standard treatment: B-blocker bisoprolol $-2.5-5 \mathrm{mg}$ once in the morning, ACE inhibitor ramipril - 5-10 $\mathrm{mg}$ once in the evening, amlodipine $-2.5-10 \mathrm{mg}$ in the evening, aspirin $-75 \mathrm{mg}$ once after lunch, atorvastatin $20 \mathrm{mg}$ once after dinner, if further 
reduction of blood pressure was needed — indapamide - $2.5 \mathrm{mg}$ once in the morning, metformin 100-1500 mg per day.

Statistical processing of results was performed using SPSS19 for Windows. Quantitative variables were described by the following parameters: median $(\mathrm{Me}), 25^{\text {th }}$ and $75^{\text {th }}$ percentiles $\left(\mathrm{Me}\left[\mathrm{Q}_{1} ; \mathrm{Q}_{3}\right]\right)$; qualitative variables were represented as the frequency of an event (percent of normal number of observations). Mann-Whitney U-test was used to compare differences between two independent samples. The frequency of features in the groups was compared using the $\left(\mathrm{X}^{2}\right)$ statistic. The binary logistic regression analysis was used to deter- mine the predictors of the mathematical model according to the analysis of 62 indicators [10].

This method investigated the dependence of dichotomous variable on the independent, which have any kind of scale, and the probability of an event depending on the values of the independent variables was calculated by the formula:

$$
\hat{P}=\frac{1}{1+e^{-z}}
$$

where $\mathrm{z}=\mathrm{b}_{1} \times \mathrm{X}_{1}+\mathrm{b}_{2} \times \mathrm{X}_{2}+\ldots+\mathrm{b}_{\mathrm{n}} \times \mathrm{X}_{\mathrm{n}}+\mathrm{a}$; $\mathrm{X}_{\mathrm{n}}$ are independence variables; $b_{1} \ldots b_{n}$ are model predictor coefficients; a - is a some constant.

\section{RESULTS AND THEIR DISCUSSION}

The analysis of clinical and anamnestic factors in the studied groups presented a significantly longer history of CHF $(p<0.014)$ and DM ( $p<0.001)$, as well as genetic susceptibility to type $2 \mathrm{DM}(\mathrm{p}<0.03)$ in patients with an adverse course of $\mathrm{HF}$, patients in the groups did not have age difference $(p>0.05)$. There were no significant differences in hereditary predisposition to $\mathrm{CHD}$ in groups with different variants of the course of $\mathrm{HF}(\mathrm{p}>0.05)$, and there were no significant differences in body/ mass index (BMI) $(\mathrm{p}>0.05)$.

In the vast majority of patients in both groups, the level of physical activity was reduced and the level of smoking was high, with a tendency to increase in the group of patients with an unfavorable course. However, levels of physical activity and smoking in groups did not differ $(p>0.05)$. In patients with an unfavorable course of HF, the values of mean arterial pressure (MAP) $(p<0.001)$, pulse pressure PP $(p<0.001)$ and heart rate $(p<0.001)$ were statistically significantly higher than in patients with a favorable course. A 6 min walk test showed similar results in both groups $(\mathrm{p}>0.05)$.

All patients presented type 2 DM. Comparing the data in both groups, a statistically significantly higher level of HbA1c $(\mathrm{p}<0.001)$, fasting glucose $(p<0.004)$, postprandial glucose $(p<0.002)$, insulin $(p<0.001)$ was revealed in the group of patients with adverse course. With a relative increase in the level of insulin resistance in all patients, it should be

\section{Carbohydrate metabolism and lipid metabolism characteristics in patients with IHD and DM type II (Me $\left.\left[Q_{1} ; Q_{3}\right]\right)$}

\begin{tabular}{c|c|c|c}
\hline Indicator, unit & Group I, (n = 66) & Group II, (n = 34) & P \\
\hline HbA1c, $\%$ & $7,0[6,6 ; 7,2]$ & $7,4[7,8 ; 7,6]$ & 0,001 \\
\hline Fasting glucose, mmol/1 & $6,05[5,78 ; 6,3]$ & $6,35[5,9 ; 6,9]$ & 0,004 \\
\hline Postprandial glucose, mmol/l & $8,4[7,8 ; 8,8]$ & $8,9[8,4 ; 9,2]$ & 0,002 \\
\hline Insulin, mcME/ml & $19,2[15,3 ; 22,6]$ & $29,3[26,8 ; 33,3]$ & 0,001 \\
\hline HOMA-ir & $4,9[4,0 ; 6,4]$ & $8,2[7,3 ; 9,4]$ & 0,001 \\
\hline TC, (mg/dl) & $233,5[224,5 ; 245,3]$ & $261,0[249,8 ; 277,0]$ & 0,001 \\
\hline TG, (mg/dl) & $167,5[156,0 ; 183,3]$ & $169,0[148,0 ; 184,3]$ & $>0,05$ \\
\hline HDL, (mg/dl) & $42,0[41,0 ; 43,0]$ & $42,0[41,0 ; 43,0]$ & $>0,05$ \\
\hline LDL, (mg/dl) & $159,0[148,6 ; 171,5]$ & $184,2[172,8 ; 197,7]$ & 0,001 \\
\hline AI & $4,6[4,3 ; 4,8]$ & $5,1[4,9 ; 5,7]$ & 0,001 \\
\hline
\end{tabular}


Results of binary classification

\begin{tabular}{c|c|c|c}
\hline \multirow{2}{*}{ Groups } & \multicolumn{2}{|c|}{ Predicted results } & \multirow{2}{*}{$\begin{array}{c}\text { Percentage of correctly } \\
\text { predicted states }\end{array}$} \\
\cline { 2 - 3 } & Group I & Group II & 98,5 \\
\hline Group I & 65 & 1 & 91,2 \\
\hline Group II & 3 & 31 & \\
\hline
\end{tabular}

noted that it was significantly higher in patients with an unfavorable course - almost twice as high as the HOMA index $(p<0.001)$ (Table 1).

Comparing the values of lipid metabolism in patients with an unfavorable course, statistically significant higher values were found for the level of TC $(p<0.001)$, LDL $(p<0.001)$, and the AI $(p<0.001)$. There was no difference between the levels of TG and HDL ( $p>0.05)$ (Table 1).

LV EF was preserved in both groups, but it was statistically significantly lower in patients of group II ( $p<0.001)$. In group II higher levels of LALD ( $p<0.001)$, mPAP $(p<0.001)$ and Dt $(p<0.001)$ were detected. The E/A ratio was higher in group I $(p<0.001)$. Differences in ESV and EDV, IVRT coefficient and $\mathrm{E} / \mathrm{e}$ ratio in both groups were not detected $(p>0.05)$.

EDD of the brachial artery was higher in patients with a favorable course of $\mathrm{HF}-9.0$ $[8.5 ; 9.6] \%$ compared with patients of group II -6.9 [5.5; 9.3]\% $(\mathrm{p}<0.001)$. The results obtained are consistent with the data of foreign and domestic authors, but despite the presence of certain differences, the determination of prognostic factors requires additional analysis.

According to the chosen method of logistic regression, the 3 most significant indicators were determined for predicting the course of HF:

- X1 - pulse blood pressure;

- X2 - endothelium-dependent vasodilation;

- $\mathrm{X} 3$ - the insulin resistance index (HOMA).

The predictors obtained will be used as prognostic factors for assessing the likelihood of adverse $\mathrm{CH}$ in each $\mathrm{CHD}$ patient in combination with DM type 2 using the following formula:

$\hat{P}=\frac{1}{1+e^{\left(0.180 \cdot X_{1}-1.494 \cdot X_{2}+3.371 \cdot X_{3}-21.016\right)}}$.
The value $\hat{\mathrm{P}}$ lies in the range from 0 to 1 and the closer the predicted probability to one, the higher the likelihood of HF. If the value $\hat{P}$ is in the range from 0 to 0.5 it is concluded that the patient has been a favorable course of the disease.

Numerical results of binary classification of objects suggests the number of correct and incorrect forecasts (Table 2).

Quality of logistic regression models was assessed using the Hosmer-Lemeshow test in which the value of $P$ is higher, the smaller the difference between the frequency observed and the predicted results. ROC analysis applied to evaluate model performance. The obtained ROC-curve shows the dependence of the proportion of correctly classified positive results on the proportion of incorrectly classified negative effects (Fig. 1).

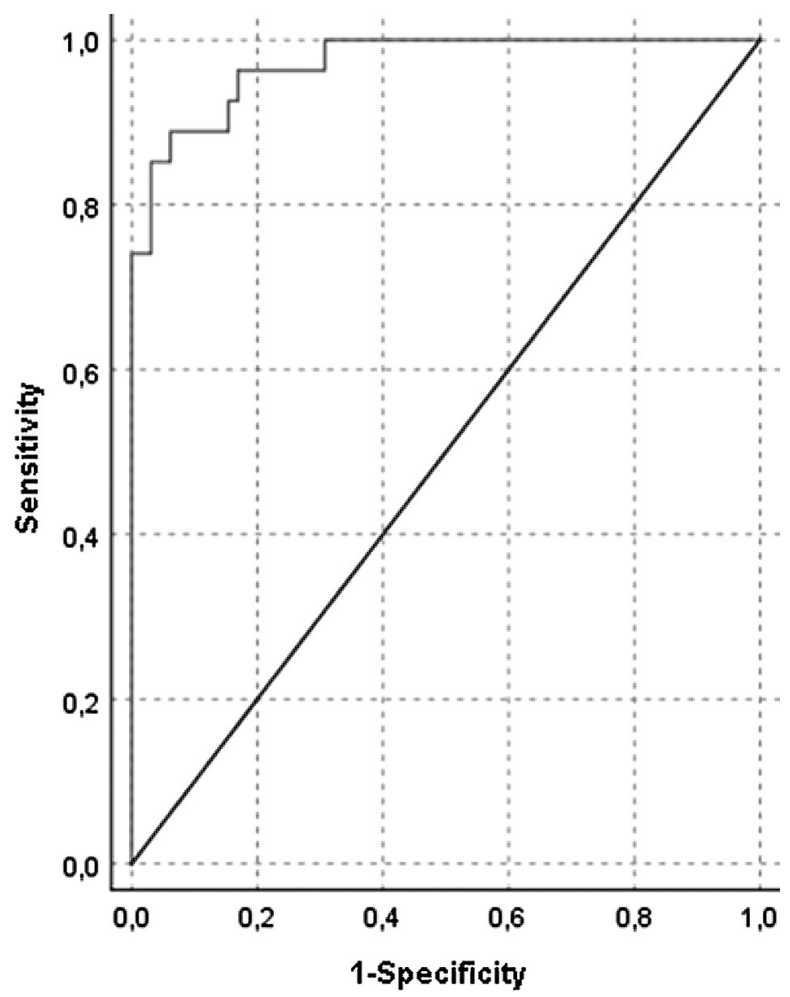

Fig. 1. ROC- curve. 
The area under curve was 0.971 (0.940, 1.000) which indicates the excellent quality of the model. Analysis of the test results of a mathematical model coefficients using Wald test showed that all variables are significant $(\mathrm{P}<0.05)$ and chosen correctly, and the equation reliably and correctly determines the state in $94.2 \%$ of cases. Can be concluded that 65 cases out of 66 are correctly classified from the total number of group I observations and 31 observations were correctly classified out of 34 from the total number of group II observations (Table 1). Thus, the total percentage of correctly classified states was $96.0 \%$, and the achieved level of significance of the HosmerLemeshov test indicates the adequacy created the model with real data.

There is a known method for predicting the risk of cardiovascular mortality in patients with various forms of HF by the level of cerebral natriuretic peptide (NT-proBNP) and tissue matrix metalloprotease inhibitor (TIMP-I) in peripheral blood, where the increase in NT-proBNP $\geq 1520 \mathrm{fmol} / \mathrm{ml}$ and TIMP-I $\geq$ $865 \mathrm{ng} / \mathrm{mL}$ allows to distinguish among highrisk patients with $\mathrm{HF}$ who require intensive treatment for both HF and complications [11].
However, the presented method does not take into account that the presence of concomitant metabolic disorders, such as metabolic syndrome, obesity and type $2 \mathrm{DM}$, can affect the prognostic value of NT-proBNP level [12].

A known method for predicting $\mathrm{HF}$ in patients with CHD uses the data of registration and qualitative dichotomous analysis of $\mathrm{LV}$ $\mathrm{EF}$ indicators, the number of heart attacks, the level of tumor necrosis factor, the variance of the QT interval or the blockade of the impulse on the electrocardiogram, the value of the final systolic size of the right atrium [13]. However, this method does not take into account concomitant type $2 \mathrm{DM}$.

Thus, on the basis of the conducted research, a method for determining the prognosis of heart failure during a year in patients with CHD in combination with type $2 \mathrm{DM}$ is proposed, by which, through additional research and determination of clinical and laboratory features with subsequent calculation, the prediction is achieved.

Using the regression equation it is possible to determine with high accuracy the probability of an adverse course of HF in patients with a preserved LV EF.

\section{CONCLUSIONS}

1. Severity of CHF with preserved LV EF in patients with IHD and DM type II is associated with disease duration and severity of lipid and carbohydrate metabolism disturbances.
2. The use of regression equations, including the study of indicators EDD, PP, HOMA it is possible to determine with high accuracy the probability of an adverse course of HF in patients with a preserved LV EF during a year.

\section{REFERENCES}

1. Ametov AS, Kurochkin IO, Zubkov AA. Rus Med Zhurn 2014; 13: 954.

2. Kuharenko SS, Jadrihinskaja MN, Drozdova EN, et al. Problemy Jendokrinologii. 2016; 62(6): 10-19.

3. MacDonald MR, Petrie MC, Varyani F, et al. Eur Heart $J$ 2008; 29: 137-138. doi: 10.1093/eurheartj/ehn153.

4. Andreas M, Zeisler H, Handisurya A, et al. Cardiovasc Diabetol 2011; 10: 28. doi: 10.1186/1475-2840-10-22.

5. Vysotska O, Dobrorodnia H, Gordiyenko N, et al. Eastern-Eur J Enterprise Technol 2016; 6(2): 15-23. doi: 10.15587/1729-4061.2016.85390.

6. Georgiyants MA, Khvysyuk OM, Boguslavska NM, et al. Eastern-Eur J Enterprise Technol 2017; 2 (4-86): 4-9. doi:10.15587/1729-061.2017.95157.
7. Rysovana L, Vysotska O, Falyova H, et al. Eastern-Eur J Enterprise Technol 2017; 1 (4-85): 40-49. doi:10.15587/ 1729-4061.2017.91428.

8. Ponikowski P, Voors AA, Anker SD, et al. Eur Heart $J$ 2016; 37 (27): 2129-2200. doi: 10.1093/eurheartj/ehw128.

9. Celermajer DS, Sorenson KE, Gooch VM, et al. Lancet 1992; 340: 1111-1115.

10. Hosmer DW, Lemeshow S. Applied logistic regression. Wiley series in probability and statistics. NY: A WileyInterscience Publication, 2015: 397 p.

11. Sandesara PB, O'Neal WT, Kelli HM et al. Diabetes Care 2018; 41 (1): 150-155. doi: 10.2337/dc17-0755.

12. Solomahina NI, Belenkov JuN. Serdechnaja Nedostatochnost' 2010; 5: 281-284.

13. Patent 11456. Sposib prognozuvannja sercevoï nedostatnosti u hvorih na ishemichnu hvorobu sercja. 


\title{
EVALUATION OF HEART FAILURE WITH PRESERVED EJECTION FRACTION IN PATIENTS WITH CORONARY HEART DISEASE AND TYPE 2 DIABETES MELLITUS
}

O. V. Bilchenko, K. Y. Lipakova ${ }^{1}$, T. A. Rudenko',

\author{
O. V. Vysotska ${ }^{2}$, A. P. Porvan ${ }^{2}$, D. Y. Karami Saliba ${ }^{1}$
}

${ }^{1}$ Kharkiv Medical Academy of Postgraduate Education, Kharkiv, Ukraine;

${ }^{2}$ National Aerospace University - "Kharkiv Aviation Institute»; Kharkiv, Ukraine ekaterinalipakova@gmail.com

The aim is to develop a method for predicting the course of heart failure (HF) in patients with coronary heart disease (CHD) in combination with type 2 diabetes mellitus (DM). The study included 100 men aged 50 to 67 years with CHD in combination with type 2 DM. Patients were divided into two groups depending on the course of HF: I $(n=66)$ - with a favorable course, II $(n=34)$ - with an unfavorable course (decreased LV $\mathrm{EF}$, patients with impaired diastolic function, and those who died during the year of observation). Analysis of cardiovascular anamnesis and indicators of carbohydrate and lipid metabolism were conducted; a transthoracic echocardiography was performed; endothelium-dependent dilation of the brachial artery (EDD) was studied. The Mann-Whitney U-test was used to determine the differences between independent samples, and the logistic regression method was used for prognosis. On the basis of the conducted research, a method for determining the prognosis of HF during a year in patients with coronary heart disease in combination with type 2 DM is proposed, by which, through additional research and determination of clinical and laboratory features with subsequent calculation, the prediction is achieved. For prognosis and subsequent calculation the formula using coefficients for prognostic factors, it is necessary to study EDD, arterial blood pressure with a calculation of pulse pressure, determine serum insulin with the calculation of the HOMA index, and use the regression equation with a high level of sensitivity and specificity to determine the probability of an adverse course of HF in patients with preserved ejection fraction.

Key words: coronary heart disease, type 2 diabetes mellitus, chronic heart failure, prognosis of the course, preserved ejection fraction.

\section{ВИЗНАЧЕННЯ ПЕРЕБІГУ СЕРЦЕВОĪ НЕДОСТАТНОСТІ У ХВОРИХ НА ІШЕМІЧНУ ХВОРОБУ СЕРЦЯ ЗІ ЗБЕРЕЖЕНОЮ ФРАКЦІЄЮ ВИКИДУ ЛІВОГО ШЛУНОЧКА У ПОЄДНАННІ 3 ЦУКРОВИМ ДІАБЕТОМ 2 ТИПУ}

\author{
Більченко О. В. ${ }^{1}$, Ліпакова К. Ю. ${ }^{1}$, Руденко Т. А. ${ }^{1}$, \\ Висоцька О. В. ${ }^{2}$, Порван А. П. ${ }^{2}$, Карамі Саліба Д. Ю. ${ }^{1}$ \\ ${ }^{1}$ Харківська медична академія післядипломної освіти, м. Харків, Україна; \\ ${ }^{2}$ Національний аерокослічний університет ілмені М. Е. Жуковського \\ "Харківський авіаційний інститут", м. Харків, Україна \\ ekaterinalipakova@gmail.com
}

Мета - розробити спосіб прогнозування перебігу хронічної серцевої недостатності (ХCH) у хворих на ішемічну хворобу серця (IXC) у поєднанні із цукровим діабетом (ЦД) 2 типу. У дослідження включені 100 чоловіків віком від 50 до 67 років з IXC у поєднанні із цукровим діабетом ЦД 2 типу. Хворі були розподілені на дві групи в залежності від характеру перебігу XCH: I (n = 66) - зі сприятливим перебігом, II (n = 34) - із несприятливим перебігом (зниження фрракції викиду лівого шлуночка, паціенти з порушенням стану діастолічної функції та ті, хто померли протягом року спостереження). Проводився аналіз кардіологічного анамнезу, об'єктивного дослідження, показники вуглеводного та ліпідного обмінів, виконувалася трансторакальна ехокардіографрія, досліджували ендотелійзалежну вазодилатацію плечових артерій (EDD). Для визначення відмінностей між незалежними вибірками використовували U-критерій Манна-Уїтні, для прогнозування - метод логістичної регресії. На підставі проведеного дослідження пропонуеться спосіб прогнозування серцевої недостатності впродовж року у хворих на IXC в поєднанні із ЦД 2 типу, за допомогою якого за рахунок додаткових досліджень та визначення клініко-лабораторних ознак з наступним розрахунком, досягаеться визначення прогнозу. Для прогнозування з наступним розрахунком за формулою з використанням коефіцієнтів до прогностичних факторів необхідно дослідити EDD, артеріальний тиск з розрахунком пульсового, визначити вміст в крові інсуліну з розрахунком індексу НОМА, та за регресійним рівнянням з високим рівнем чутливості та специфічності прогнозувати у пацієнтів зі збереженню фракцією викиду ймовірність несприятливого перебігу серцевої недостатності.

К лючові слова: ішемічна хвороба серця, цукровий діабет 2 типу, хронічна серцева недостатність, прогнозування перебігу, збережена фрракція викиду. 


\section{ОПРЕДЕЛЕНИЕ ТЕЧЕНИЯ СЕРДЕЧНОЙ НЕДОСТАТОЧНОСТИ У БОЛЬНЫХ ИШЕМИЧЕСКОЙ БОЛЕЗНЬЮ СЕРДЦА В СОЧЕТАНИИ С САХАРНЫМ ДИАБЕТОМ 2 ТИПА С СОХРАНЕННОЙ ФРАКЦИЕЙ ВЫБРОСА ЛЕВОГО ЖЕЛУДОЧКА}

Бильченко А. В. ${ }^{1}$, Липакова Е. Ю. ${ }^{1}$, Руденко Т. А. ${ }^{1}$, Высоцкая Е. В. ${ }^{2}$, Порван А. П. ${ }^{2}$, Карами Салиба Д. Ю. ${ }^{1}$

${ }^{1}$ Харьковская медицинская академия последиплолного образования, г. Харьков, Украина;

${ }^{2}$ Национальный аэрокосмический университет илени Н. Е. Жуковского "Харьковский авиационный институт», г. Харьков, Украина ekaterinalipakova@gmail.com

Цель - разработать способ прогнозирования течения хронической сердечной недостаточности $(\mathrm{XCH})$ у больных ишемической болезнью сердца (ИБС) в сочетании с сахарным диабетом (СД) 2 типа. В исследование включены 100 мужчин в возрасте от 50 до 67 лет с ИБС в сочетании с СД 2 типа. Больные были разделены на 2 группы в зависимости от характера течения XCH: I (n = 66) - с благоприятным течением, II (n = 34) - с неблагоприятным течением (снижение фракции выброса левого желудочка, пациенты с нарушением состояния диастолической функции и те, кто умерли в течение года наблюдения). Проводился анализ кардиологического анамнеза, объективного исследования, показателей углеводного и липидного обменов, выполнялась трансторакальная эхокардиография, исследовали эндотелийзависимую вазодилатацию плечевых артерий (EDD). Для определения различий между независимыми выборками использовали U-критерий Манна-Уитни. Частоту признаков в группах сравнивали с помощью критерия $\mathrm{x}^{2}$. Для прогнозирования использовали метод логистической регрессии. На основании проведенного исследования предлагается способ прогнозиррвания сердечной недостаточности течение года у больных ИБС в сочетании с СД 2 типа, с помощью которого за счет дополнительных исследований и определения клинико-лабораторных признаков с последующим расчетом, достигается определение прогноза. Для прогнозирования с последующим расчетом по формуле с использованием коэффициентов к прогностическим факторам необходимо исследовать EDD, артериальное давление с расчетом пульсового, содержание в крови инсулина с расчетом индекса НОМА, с помощью регрессионного уравнения с высоким уровнем чувствительности и специфичности можно прогнозировать у пациентов с сохраненной фракцией выброса вероятность неблагоприятного течения сердечной недостаточности.

К л ючевые слов а: ишемическая болезнь сердца, сахарный диабет 2 типа, хроническая сердечная недостаточность, прогнозирование течения, сохраненная фракция выброса. 